\title{
God as One
}

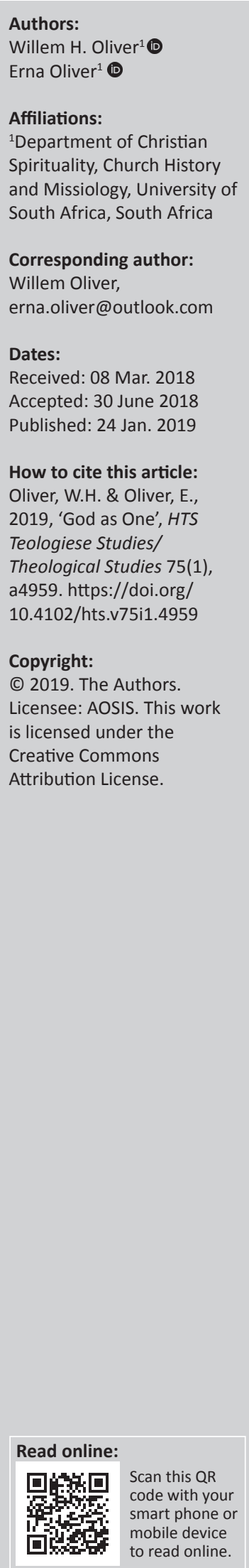

Two notions are discussed in this article, namely, the (unity of the) Trinity and God's omnipresence. These two notions are deeply embedded in the Christian faith system and religion - they actually form both the basis and point of departure for the Christian religion. The aim of this article is to revisit the (Early Church and present) dogma of the Church about the Trinity and omnipresence of God as a result of the heresies and apologies linked to this dogma, and to rethink the notion of the concept 'Trinity' linked to God's omnipresence. The historical method is used in the discussion of the (primary) sources and to reach the outcome.

\section{Introduction ${ }^{1}$}

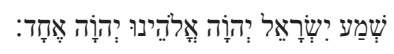

[Israel, you must understand: Yahweh, our God, is ONE Yahweh - Dt 6:4].2

It is the firm conviction of the authors that God is one eternal God, and not three separated Persons, acting in a unique way as one. Our research starts with the Old Testament times, where God presented himself to his people as one God, named Yahweh. The people of God knew him and believed in him as one God with one Name. ${ }^{3}$

The Old Testament witnesses to the fact that God's people have strayed so far away from him, not giving heed to all the prophets being sent to them by God, that, after two different exiles and still no better relation, God has decided to physically come to earth to put mankind in the right relation with him. As the family was a very precious metaphor to the Jews - and for that matter also to the other nations - and society was structured along kinship lines, so God made use of that metaphor when he came as Jesus - the Son of God. Seemingly, the presentation of Jesus as Son of God, complemented by the promise of the Holy Spirit, gave rise to the idea that Yahweh was actually three (separate) Persons. ${ }^{4}$ To the best knowledge of the authors, the earliest documents depicting Yahweh (кúpros - God) within the family metaphor of Father, Son and Holy Spirit, are the letters of Paul, as well as the Gospels.

The term Trinity does not occur in the Bible. However, today it is a common term referring to God. Most (Reformed) Churches depict the Trinity with a common picture, being presented in their catechetical books, mostly without an elaborative explanation. The picture looks something like Figure 1.

Reformed Churches moreover have the conviction that one should not deliberate too much about the holy Trinity, as one cannot really explain this concept or notion. Their words find its origin in Origen, when already stated in the 3rd century in his De Principiis 4.28 that it is almost impossible to talk about the Trinity. ${ }^{5}$

\footnotetext{
1.The authors take note of the theology of Richard w Jenson, who is a highly regarded scholar on the Trinity, but do not refer to him in this article as this article discusses the Trinity from another vantage point (cf. Verhoef 2011:247)

2.This verse, which was the shema of Israel (cf. Garlington 2008:39), can also be translated with, Israel, remember this! The Lord-and the Lord alone - is our God (Good News Translation), or Hear, o Israel: The Lord our God, the Lord is one (NIV). We also find these words in the New

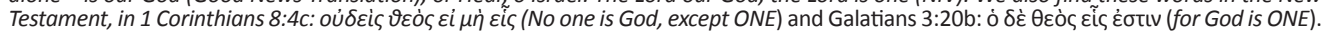

3.Up to this very day, they still believe in one God with one Name - and many titles.

4.A good example is found in the 4th-century document, De Spirito Sancto by Basil the Great, in chapter 29 (Schaff 1885h:240), where he referred to both Dionysius of Alexandria (a part of his Libris adversus Sabellium that is not extant anymore) and Clemens Romanus referred to both Dionysius of Alexandria (a part of his Libris adversus Sabellium that is not extant anymore) and Clemens Romanus
(Epistle to the Corinthians chapter 58 - that part of chapter 58 is lost): Dionysius, moreover, in the middle of his treatise thus writes in (Epistle to the Corinthians chapter 58 - that part of chapter 58 is lost): Dionysius, moreover, in the middle of his treatise thus writes in
opposition to the Sabellians, 'If by the hypostases being three they say that they are divided, there are three, though they like it not. Else let them destroy the Divine Trinity altogether'. And again: '... most Divine on this account after the Unity is the Trinity'. Clement, in more primitive fashion, writes, 'God lives, and the Lord Jesus Christ, and the Holy Ghost'.

Further research is needed about the transition from a monotheistic religion (especially for the Jews as nation of God) to a Christian religion, where the world became the nation of God, and where they started to believe in the Father, the Son, and the Holy Spirit as three separate Persons.

5. Haec enim sola Trinitas est quae omnem sensum intelligentiae non solum temporalis, verum etiam aeternalis excedit (For it is the Trinity alone that exceeds the comprehension not only of temporal but even of eternal intelligence - Migne 1857c:455). This forms part
} of De Principiis 4.28-37, which is his Summary (of doctrine) regarding the Father, the Son, and the Holy Spirit.

Note: The collection entitled 'God as One', sub-edited by Erna Oliver (University of South Africa) and Willem Oliver (University of South Africa). 


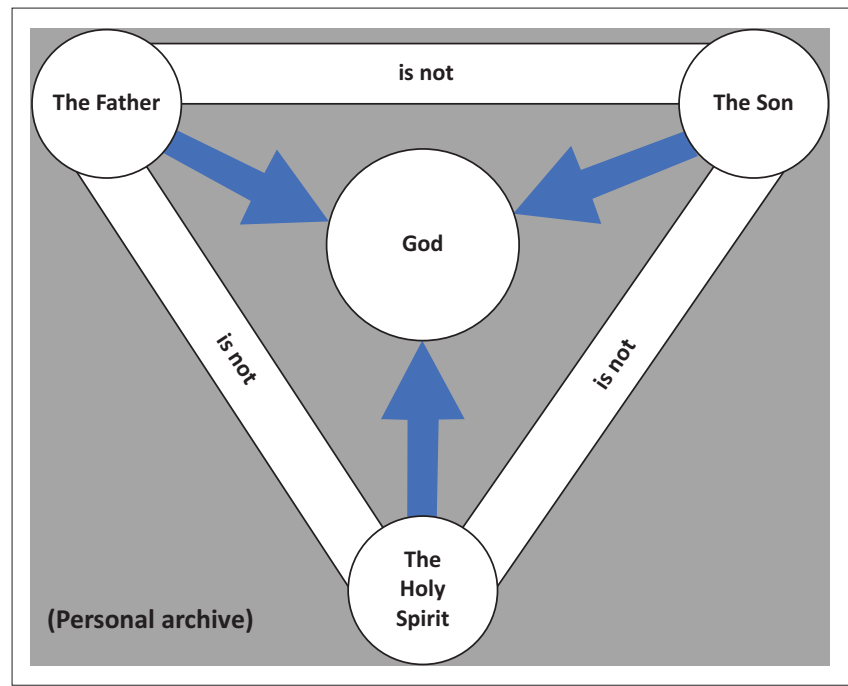

FIGURE 1: The Trinity.

The epistemology of the holy Trinity - not seeing him as ONE God, but as three 'separate' Persons, opened the door for many Churches (in South Africa) to worship God by giving priority to one or two Persons of the Trinity, while neglecting the other one or two (as if God can be split up): Most Reformed Churches prioritise the Father and mostly the Son, while most Charismatic and Pentecostal Churches are more focused on the Son and the Holy Spirit. This kind of worship does not really refer to a Trinity (as unity) being worshiped, but in fact a tripartite religion in which God is being separated into three distinct Persons.

While most languages translate the terms Yahweh [Old Testament] and Kurios [New Testament] with a singular noun, for example, Lord [English], Dios [Spanish], and Deus [Latin], some languages like Dutch and Afrikaans give the impression that these translations may have a plurality of Persons in mind, as they translate the term with Heere [Dutch] and Here [Afrikaans] (cf. Gn 2:4). ${ }^{6}$ This is seemingly in harmony with Genesis 1:26 (emphasis added ${ }^{7}$ ): Then God said, 'Let us make mankind in our image, in our likeness, so that they may rule ...'. From this verse many scholars have concluded that Yahweh consists of more than one Person $^{8}$ (cf. Armstrong 1962:39, 69). However, Westermann (1984:145; cf. also Schmidt 1964:128) regards the expression 'Let us' as a plural of deliberation, in fact referring only to one Person. ${ }^{9}$

\section{With this in mind, Die Boodskap (Van der Watt \& Joubert 2002), one of the recent translations in Afrikaans, refers in quite a few passages in the New Testament to God the Father and Jesus as 'them', clearly implicating a plurality, while the Greek text does not support that: (1) 1 Corinthians 1:3: Mag God ons Vader en ons Here Jesus Christus baie goed wees vir julle. Mag Hulle julle innerlik rustig maak en vrede gee. (2) Ephesians 1:2 Mag God, die Vader, en die Here Jesus Christus vir julle goed wees...Mag Hulle vir julle vrede gee soos net Hulle kan. (3) 2 Thessalonians 2:16-17: Ek bid dat Christus en God julle ook met hierdie goeie nuus sal troos ... Mag Hulle julle sterk maak..}

7.Without stating it every time, all the emphases in the biblical texts are added.

8.According to the Epistle of Barnabas 5 (cf. Schaff 1885b:375), these were the words uttered by God, the Father, to his Son; cf also The Pastor of Hermas Similitudes 9 , chapters 12 and 14 (1885b:96-98) postulating that the Son was in conversation with the Father during the creation process.

9.According to Joüon (2005:266-271), the pluralis majestatis (plural of majesty) is a Fremdkörper in biblical Hebrew, occurring only in Ezra 4:18. The plural of deliberation also occurs in Genesis 11:7, 2 Samuel 24:14 and Isaiah 6:8.
The above is the one side of the coin. On the other side, there are certain Church groups that have the conviction of a Christian Unitarianism. The United Pentecostal Church (cf. Torell 2018) and United Apostolic Church (cf. United Apostolic Church 2018) are denying the Trinity, teaching that God's Name actually is Jesus. The Jehovah's Witnesses (cf. Jehovah's Witnesses 2018) and the Jewish community think that God is unipersonal (cf. Jews for Jesus 2018). These Churches are accusing the Trinitarian Churches of teaching three gods, despite the fact that the dogma of the Trinitarian Churches depicts the Trinity as one God in three eternal coexistent Persons: The Father, the Son, and the Holy Spirit.

There are also people who believe, just like Arius (discussed below), that God made Jesus, and that Jesus is therefore a lesser God (cf. Jn 14:28). A good example is to be found on Triumphpro (s.a.), indicating, with reference to the Bible and Church Fathers that God is not a Trinity, but:

that Christ, as the Logos, was Himself originally a CREATED BEING, who BECAME part of the God-head - just as true Christians will one day become part of the Universe-ruling FAMILY OF GOD! (Triumphpro s.a.)

With the above in mind, the aim of this article is to revisit the (earliest and present) dogma or dogmas of the Church about the Trinity and omnipresence of God as a result of the heresies and apologies linked to this dogma, and to rethink the notion of the concept 'Trinity' linked to God's omnipresence. Chronologically, the Bible should be discussed first, but it will be discussed last, because as the Word of God it has authority over all the documents and theologies discussed in this article.

\section{The Early Church Era: Different 'theologies'}

The interpretation of the Word of God goes back to the earliest days of Christianity. ${ }^{10}$ From the outset of Christianity - after the Ascension of Jesus (cf. Mt 28:16-20) - the Good News was in the mouths and the memories of his apostles. After God poured out his Holy Spirit on the apostles (Ac 2:1-13), they started to share the gospel about Jesus with (mostly) the Jews and proselytes, and a little later with the gentiles.

However, because Jesus' apostles and other preachers of the gospel, like Apollos (Ac 18:24; 1 Cor 1:12; 3:4-22), Stephen (Ac 6:5-7:60), Philip (Ac 8:4-40), and Paul, did not have a 'Christian manual' - they were not trained by Jesus himself to assist them, the proclaimed gospel did not always display an unambiguous tone. A few examples are given to support this argument:

- Apollos, who had been instructed in the way of the Lord, spoke with great fervour and taught about Jesus accurately, though he knew only the baptism of John (Ac 18:25). Oden (2011:143) calls him a 'messianic Jew', born in

10.Though the terms 'Christian' and 'Christianity' are used in this article, it is important to take note that these terms were unknown to the 1 st-century followers of Christ. According to Acts 11:26, the term 'Christianity' was first used in Antioch (in Syria) According to Acts 11:26, the term 'Christianity' was first used in Antioch (in Syria)
in the writings of Ignatius (ca 35-107), the second (or third) bishop of Antioch in in the writings of Ignatius (ca 35-107), the
the 2nd century CE (cf. McGrath 2013:1). 
Alexandria, and preaching the Good News there (probably as early as the 40 s or 50 s of the 1st century), as well as other places, but initially with very little knowledge. Acts 18:26 reports how Priscilla and Aquila (also not trained by Jesus himself) took Apollos to their house in Ephesus and explained to him the way of God more adequately.

- Stephen and Philip were two deacons (cf. Ac 6:5) who proclaimed the Good News (cf. Ac 7-8). It is not clear whether they were part of the bigger group of Jesus' disciples.

- Saul, who initially was no friend of the Christians, was called by God ('Jesus') to become a missionary to the gentiles. Later known as Paul, he claimed to be an apostle by the will of Christ (1 Cor 1:1) and by the will of God (2 Cor 1:1). Because he was not part of the group of disciples of Jesus, and actually did not know Jesus in person, his theology differed to some extent from those who walked with Jesus. One significant example will suffice: While (according to the Gospels) Jesus focused in his preaching on the kingdom of heaven (cf. Mt 8, 10, 11 \& 13), ${ }^{11}$ the kingdom of God (cf. Mk 4, 9, 10), and eternal life (cf. Jn 3-6, 10, 12, 17), Paul focused more on justification by faith, especially in his Epistle to the Romans (cf. Rm 1:16-17).

- Acts 19:1-5 relates how Paul rebaptised some followers of Jesus ('disciples') in Ephesus who were baptised with the baptism of John but did not know of the Holy Spirit. According to Paul, John's baptism was a baptism of repentance (Ac 19:4; cf. Mt 3:11), and therefore he rebaptised them in the Name of Jesus. Interestingly, Jesus (seemingly also all his disciples [Ac 1:5]) was only once baptised, by John (Mt 3:13-14), while at his Ascension he ordered his disciples to baptise the converts in the Name of the Father and of the Son and of the Holy Spirit (Mt 28:19). More interestingly, we read in Acts 10:48 that Peter baptised people only in the Name of Jesus.

- When the books of the New Testament were penned down, mostly during the latter part of the 1st century, the oral content of the four Gospels slightly differed from each other, although the broad message of Jesus was uncompromised.

It is understandable that the more preachers or missionaries there were, the more the gospel became a multiplex, multidimensional message. This soon gave rise to 'heresies' such as Arianism, Modalism and Sabellianism, to name but a few. In turn, these heresies gave rise to the documentation of apologies by the early Church Fathers, resulting in the first dogma ('Christian manual') of the Church, set mostly at the Ecumenical Councils between the 4 th and 8 th centuries.

Despite the mentioned differences in the preaching of the first followers of Christ, one thing stood firmly: All of these people were true followers of Jesus, and all of them proclaimed the Good News to get people converted by the Holy Spirit.

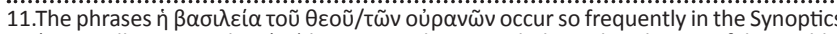
(especially in Matthew), 'that it can be regarded as the theme of his public preaching in Galilee' (Oliver \& Van Aarde 1992:387; cf. Schmidt 1969:580-590).
The question can be asked if this epistemology can also be applied to the heresies that would come into existence during the Early Church Era.

\section{The heresies ${ }^{12}$}

As an introduction to the heresies, it should be stated that most of the 'heretics' can be identified as committed Christians, but with views that were not in line with those of the Church. Because of the fact that the gospel was not at first written down, the words of the different apostles in different places gave rise to different opinions and points of view (discussed above). Under this heading, opinions that were contra the viewpoint of the Church, more specifically the heresies concerning the Trinity, are discussed, limited to Modalism, Sabellianism and Arianism.

\section{Modalism}

Modalism $^{13}$ is a late 2nd-century doctrine (Von Harnack 1961:166), holding that the Father, the Son (Jesus), and the Holy Spirit are only 'masks' or instances of the one God and not three distinct Persons or realities within God (Deist 1984:148; McGrath 2013:359; Williams 2011:1539). It describes a kind of Christian Unitarianism, advocating the primacy of Christian monotheism. From this view, the term patripassianism or patripassionism (see Sabellainism) originated, claiming that the Father suffered just as much on the cross as the Son (cf. Schaff 1885f.:757; Williams 2011:1539). The first proponent of Modalism was Noetus of Smyrna during the last decade of the 2nd century (Kelly 1978:120). According to Hippolytus, Noetus alleged that Christ was in fact the Father himself, ${ }^{14}$ that the Father was also born, ${ }^{15}$ and that he suffered and died on the cross ${ }^{16}$ (Marcovich 1986:403; Williams 2011:1540).

Monarchianism (from the Greek noun $\mu$ ov $\alpha \rho \chi i \alpha$ that can be translated with single principle) manifested in two forms, that is, dynamic and modalistic, and first appeared at the end of the

12.According to Deist (1984:73), this is a doctrinal view that is at variance with the recognised, established and official doctrine of a church. The term 'heresy' has its

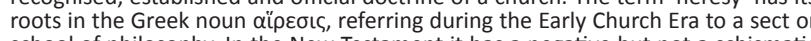
school of philosophy. In the New Testament it has a negative but not a schismatic connotation. Louw and Nida (Vol 1 1988) find three sets of meanings for this term aipectc: $\mathrm{A}$ division or group based upon different doctrinal opinions and/or loyalties and hence by implication in certain contexts an unjustified party or group (religious party) (Louw \& Nida, Vol 1 1988:129). Texts belonging to this group are Acts 24:14 (here the Jews called the 'followers of the way' [Jesus followers] ( sect - cf. also Ac 24:5; 28:22), Acts 26:5 (where Paul calls the Pharisees a strict sect; cf. also Ac 15:15 [Pharisees]) and Acts 5:17 (Sadducees). aipecolc: the content of teaching which is not true - 'false teaching, untrue doctrine' (Louw \& Nida, Vol 1988:415). In 2 Peter $2: 1$, the writer warns against people who introduce

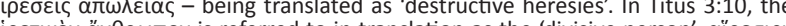

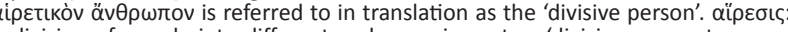
A division of people into different and opposing sets - 'division, separate group' (Louw \& Nida, Vol 1 1988:616). 1 Corinthians 11:19 denotes to divisions or factions in the church. In Galatians 5:20, Paul ranks 'heresies' (factions) with crimes and seditions.

13.The term 'Modalism' was first coined in the early 20th century by Von Harnack (Williams 2011:1539)

14. Hippolytus stated in his Refutatio 10.23: toũtov oũv tòv ratépa aútòv kai viòv óvouáłouøl (and they call this Father himself the Son) (Marcovich 1986:403). Hippolytus wrote another document against Noetus, called Contra hæresin Noeti cujusdam (Migne 1857b:803-828).

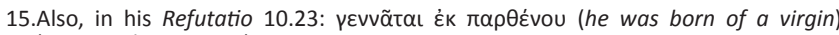
(Marcovich 1986:403).

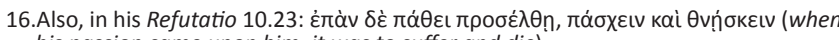
his passion came upon him, it was to suffer and die). 
2nd century CE. Dynamic Monarchianism - being brought to Rome by Theodotus (a leather merchant from Byzantium) also called Adoptionism, depicted Jesus as being adopted by God at his baptism. Hippolytus ${ }^{17}$ and Eusebius of Caesarea ${ }^{18}$ referred mostly to this point of view.

Modalistic Monarchianism took monotheism, which was the bedrock of Christianity, as their starting point. However, to hold true to monotheism, they rejected the deity of Jesus. Praxeas of Smyrna was a Modalistic Monarchian (Evans 1948). Tertullian, in his Adversus Praxean (Evans 1948; cf. Schaff 1885c:1334-1411), constantly attacks Praxeas for not recognising the Trinity as three Persons. Against Praxeas, who maintained the unity of God by 'declaring the Trinity to be mere personae or temporal modes of the one divine substance' (Williams 2011:1539), Tertullian states: maxime haec quae se existimat meram veritatem possidere dum unicum deum non alias putat credendum quam si ipsum eundemque et patrem et filium et spiritum sanctum dicat [especially in the case of this heresy, which supposes itself to possess the pure truth, in thinking that one cannot believe in one only God in any other way than by saying that the Father, the Son, and the Holy Spirit are the very same Person (Tertulliani Adversus Praxean 2; cf. also Tertulliani Adversus Praxean 13); Evans 1948:90; 102-103].

\section{Sabellianism}

While the West called this heresy Patripassianism, the Eastern Church called it Sabellianism, after its founder, Sabellius, an early 3rd-century priest and theologian (Hist Eccl 7.6; Migne 1857f:646-648; Schaff 1885f:757). It was closely linked to Modalism. Eusebius (Hist Eccl 7.6) judged this heresy as

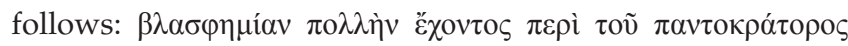

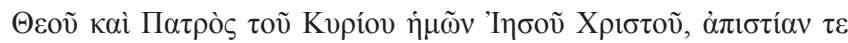

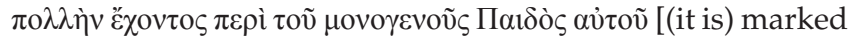
by great blasphemy against the almighty God, the Father, and our Lord Jesus Christ, and contains much unbelief respecting his only begotten Son - Migne 1857f.:648)]. Dionysius of Alexandria confirmed this in his Libris adversus Sabellium [of which only fragments remained] about Sabellius:

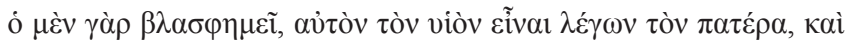
$\ddot{\varepsilon} \mu \pi \alpha \lambda v$ [for he blasphemes in saying that the Son himself is the Father, and vice versa; Routh 1846:373].

Sabellianism was used as a general term by the Church Fathers during the 4th and 5th centuries, when referring to various forms of Monarchianism, all of which denied a personal distinction in the Godhead (Schaff 1885f.:757). Sabellius, probably a popular teacher in Rome, was condemned by the bishop Callistus in approximately 220 (Williams 2011:1540).

While Modalism mostly flourished in the West, Sabellianism flourished in both the Western and Eastern Church. During the 4th century, the Cappadocian Fathers in the Eastern

17.See his Refutatio Omnium Haeresium [The Refutation of all heresies] 7.23 (Marcovich 1986:292-293).

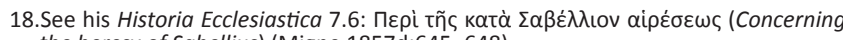
the heresy of Sabellius) (Migne 1857d:645-648).
Church and Augustine of Hippo consolidated the doctrine of the Trinity, therefore rejecting the view of the Sabellianism (McGrath 2013:59).

\section{Arianism $^{19}$}

Origen (185-254) wrote extensively, and sometimes hastily dotted words down that could easily be misunderstood (cf.

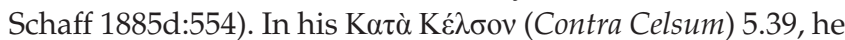

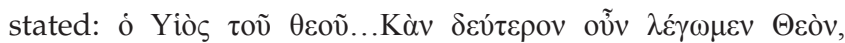

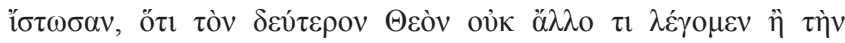

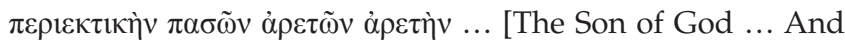
although we may call him a second[ary] God, let them know that by (the term) 'second God' we mean nothing else than a virtue capable of including all other virtues ... - Migne 1857e:1243-1244].

In a meeting in Alexandria in 318, Alexander, the bishop of Alexandria, referred to the eternity of the Son as God. Arius (250/256-336), a native of Libya who settled in Alexandria (Schaff 1885g:21) and became an ascetic Christian presbyter and priest in the city (Schaff 1894:134), interpreted the words of Origen (in the previous paragraph) that Jesus was a lesser ('secondary') God and immediately accused Alexander of Sabellianism. Influenced also by Neo-Platonism, he suggested that Jesus, being the Word, the Logos, the Son, was secondary and subordinate to God (the Father). Arius postulated that Jesus was not Divine but was created to be ranked 'first among the creatures' (cf. McGrath 2013:56). He argued that although Jesus formed part of the Trinity, the Father, who was totally transcendent and immutable, was the ultimate source of authority and chose to act through Jesus and the Holy Spirit.

In his Oratio contra Arianos 4, Athanasius differed from Arius specifically on two points ${ }^{20}$ : Firstly, only God the Creator can redeem the creation. Jesus was not redeemed and was therefore God, as God has redeemed everything to him. Jesus Christ is therefore the Saviour and, while it is only God who can save, Jesus must have been God incarnate, as is clear from John 1:14. Secondly, Christians worshipped and prayed to Jesus. If Jesus were a mere creature, then the Christians who worshipped and prayed to him would be sinning.

In 321, Alexander arranged a meeting in Alexandria and excommunicated Arius and his followers (Isichei 1995:23; Schaff 1894:134). The Roman emperor, Constantine, then called the first Ecumenical Council in Nicaea in 325, where 19.Burton (2007:128) called Arianism the 'arch-heresy for orthodox Christianity'.

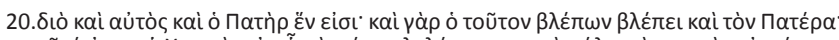

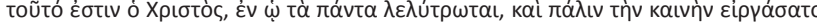

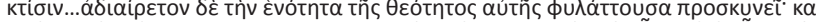

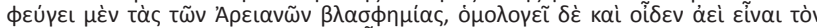

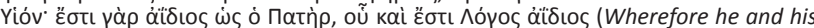
Father are one and whoever looks at him, looks at the Father, and the Christ in Father are one, and whoever looks at him, looks at the Father, and the Christ, in whom all things are redeemed, and the new creation wrought afresh ... and it guards as indivisible and worships the unity of the Godhead himself; and shuns the Arian blasphemies, and confesses and acknowledges that the Son was ever; for he is eternal, as is the Father, of whom he is the eternal Word [Oratio contra Arianos 4 with reference to the Thalia of Arius] - Khazarzar 2006b:10-11). Only thre fragments of Arius' Thalia remained, being referred to by Athanasius in his Oratio contra Arianos. In this book, he seemingly noted all his arguments and views on the Trinity. 
the doctrine of Arius was formally condemned and the Nicene Creed was adopted, consisting of the words: [We believe] in one Lord, Jesus Christ, the only begotten Son of God, begotten from the Father before all ages, light from light, true God from true God, begotten not made, of one substance with the Father, through whom all things came into existence (Early Church Texts s.a.). ${ }^{21}$

In 336, Arius died in Constantinople, a 'broken, and largely forgotten man' (Isichei 1995:24), but only after the reign of emperor Theodosius the Great in 395 did the influence of Arianism fade. ${ }^{22}$

\section{Actions of the Church against (these) heretics}

Because of the heresies mentioned above (as well as many others), it was imperative for the Church during these early years of the new religion to give account of their belief and faith system. However, it is very important to acknowledge that these 'heretics' were not atheists or devoted to another religion, but that they were devoted Christians, though with unacceptable (for the Church and the gospel) beliefs. The earliest Church took action (consciously or unconsciously) against the heresies to consolidate their faith. Three actions are distinguished, namely the fixation of the canon of the Bible, the Ecumenical Councils, and apologies being written by Church Fathers (of which some are already referred to). Much later, the Three Forms (Formularies) of Unity were added. These actions did not put an end to the heresies but rather concluded a belief system for the Church on which the Church could stand - to do missionary work and to defend itself.

\section{The fixation or formation of the Bible ${ }^{23}$}

In this article, the term Bible refers to the Christian Bible comprising of 66 books - traditionally divided into two 'Testaments' called the Old and the New Testament, and therefore excluding the Apocrypha of both Testaments as well as the Pseudepigrapha. The books of the Old Testament in its original form were (mostly) written in Hebrew (and Hebrew dialects) during the days before Christ, and those of the New Testament in (koine) Greek, mostly written during the second half of the 1st century CE. The Masoretic Text originates from the late-1st or early-2nd century and was regarded to be the official Old Testament text for both Judiasm and Christianity (cf. Evans \& Tov 2008:16). The Septuagint (LXX) is a Greek translation of the documents contained in the Old Testament, which already originated

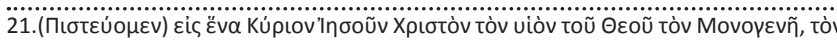

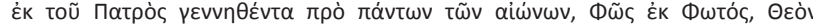

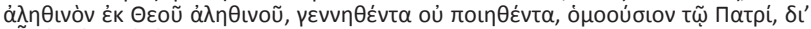

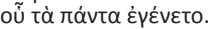

22.According to the Encyclopedia Britannica (Britannica Concise Encyclopedia 2006:101), the Christology of the Jehovah's Witnesses is a form of Arianism, as they regard Arius as a forerunner of Charles Taze Russell, the founder of their movement.

23. For a good portrayal of the history of the Bible, the reader is referred to, inter alia, Evans and Tov (2008) from the 3rd century BCE. At the Council of Laodicea ${ }^{24}$ in 363, the canon of the Bible was concluded in Canon 60. Interestingly, almost a century before that, Athanasius has already indicated the books of the New Testament in his Epistola Festalis 39.5 (Easter Festal Letter 39 or Chronicum Athanasianum), preceded by 22 books of the Old Testament (Epistola Festalis 39.4; Khazarzar 2006a:1; Schaff 1885g:1346). By the end of the 4 th century (382 CE), Pope Damascus 1 requested Jerome to translate the Bible into Latin, called the Vulgate, which became the official Bible of the Roman Catholic Church.

\section{The Ecumenical Councils ${ }^{25}$}

Constantine, after declaring Christianity a state religion in 313, became aware of the differences within Christianity in his Empire and convened the First Council at Nicaea in 325. $\mathrm{Six}^{26}$ more Councils followed, where the Church delivered verdicts on different interpretations and also formulated confessions of faith to stipulate what Christianity stood for at the time. Only decisions related to this article are mentioned.

At the first Council, the Creed (Symbolum) of Nicaea was decided on, pointing out (against Arius) the true Divinity

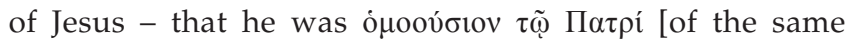
substance as, consubstantial with, or of one essence with the Father (Early Church Texts s.a.)]. The Council decreed that Jesus, the Word, and Son of God, has been eternally 'begotten' ( $\gamma \varepsilon v v \eta \theta \varepsilon \dot{\varepsilon} \tau \alpha)$ from the Father and was not created. He was incarnate (made flesh) of the virgin Mary and became human (Early Church Texts s.a.). The second Council, in Constantinople (381), reaffirmed this belief in the full Divinity of Jesus and added the true Divinity of the

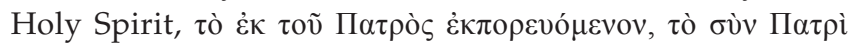

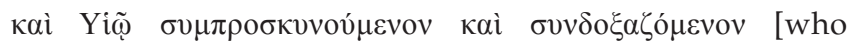
proceeds from the Father, who with the Father and the Son is together worshiped and together glorified - Early Church Texts s.a.]. In the fourth Council, at Chalcedon (451), the 'Chalcedonian Definition' was accepted,

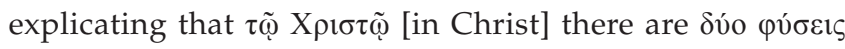

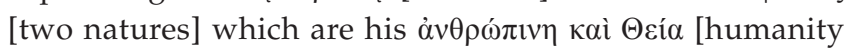
and Divinity] - they are $\dot{\alpha} \delta 1 \alpha \imath \rho \varepsilon ́ \tau \omega \varsigma$ [united or undivided or indivisible], $\dot{\alpha} \tau \rho \dot{\pi} \tau \tau \omega \varsigma$ [unchangeable], $\dot{\alpha} \mu \varepsilon \rho i ́ \sigma \omega \varsigma$ [without being separated or inseparable], and $\dot{\alpha} \sigma v v \chi v i \omega \varsigma$ [without being confused together or immutable] (Coleti 1727:1452). The sixth Council, at Constantinople (680-681), decided that in Jesus Christ there are two energies and two wills corresponding to his two natures (Schaff 1885j:657). The purpose of this conciliar teaching was to protect the doctrine of the fullness and completeness of both Jesus' humanity and Divinity.

24.This Laodicea where the Synod met was Laodicea in Phrygia Pacatiana, also called Laodiceaad Lycum, which is to be distinguished from Laodicea in Syria.

25.For an exhaustive discussion on these Councils, read Schaff (1885j).

26.According to the Roman Catholic Church, there were eight Councils, the eighth one being the Fourth Council of Constantinople in 869, under Pope Hadrian 2 and emperor Basil, where Photius was condemned for unlawfully seizing the patriarchal dignity (Thornton 2007:121-130; cf. also Synaxis.info s.a.). 


\section{Apologies $^{27}$}

As Christianity developed, the champions of the newly founded religion had to justify and defend it against other religions, even other 'theologies' and heresies, thereby creating an early Christian apology which prevailed from the late-1st century until at least the 5th century CE. Christian

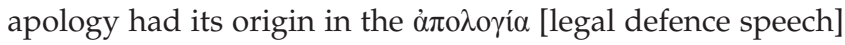
first used by a rhetoric teacher, Antiphon of Rhamnus, in the 5th century BCE (cf. Ulrich 2014:7). Eusebius was the first ancient writer to use this term in a reference to a collection of early texts that defended the Christians (Hist Eccl 4.8.3; 17.1). As the early apologists did not write their documents within a legal environment, they mostly did not refer to their texts as apologies, but rather as letters, objections, applications or petitions (Ulrich 2014:7), 'addressed to someone who was hostile to Christianity' (Hyldahl 2014:139). Three factors gave rise to the founding of the 'early Christian apologetics' (Ulrich 2014:1):

- Apology was founded for the sake of defence and evangelism.

- The earliest apologists pointed to specific misunderstandings of outsiders and replaced it with 'the truth'.

- The apologists also gave elucidatory answers to questions asked by the followers of Christ.

The apologists played an important role, because they held a mirror to the conflicting aspects of various belief systems. Theirs was a first real attempt to systematise the Christian religion and, doing so, contributing much to the development of a theology of Christianity. Their writings supplemented the reading of Scriptures, in this way contributing to the spread of the Christian religion, for both believers and nonbelievers (cf. Fogarty 2004:124).

A few years after the Ascension of Jesus, Paul defended and justified himself before the followers of Jesus in Jerusalem. This was actually the first apology known of in the Church (cf. Ac 21:17-23:11). However, Aristides and Quadratus were the first official apologists. While the latter's work is lost in total, the former's Apology was discovered in 1889. This Apology dates back to $125 \mathrm{CE}$ when Aristides presented it to emperor Hadrian (Pedersen 2014:35; cf. Schaff 1885e:499). The Church Fathers also were apologists, who detected certain actions in the Church that were contra the doctrine of the Church and who started to write documents to that effect. Examples of apologists are Justin Martyr, Clement of Alexandria, Origen, and Tertullian, although there are many more.

Justin Martyr and Tertullian are highlighted here. Justin Martyr (100-165) was the first apologist in Africa with works like Apologia prima pro Christianis, Apologia secunda, and Dialogus cum Tryphone Jedaeo (Migne 1857a:327-802). In his

27. Many apologies were written about/in defence of the Trinity. That is a piece of research on its own, as space does not allow us to include all of them in this article. research on its own, as space does not allow us to include all of them in this article.
A good book to consult is Simpson (1798), chronologically covering the viewpoints on the Trinity from Old Testament times to the Councils. first two apologies he addressed emperor Antoninus Pius and the Roman Senate respectively and told them that philosophical wisdom was false and hollow contrasted to the wisdom of Jesus. In his Dialogus cum Tryphone Jedaeo he presented the learned Jew (Trypho) with the similarities between the new religion and Judaism, showing him that Jesus was already foreshadowed by various Old Testament figures like Moses, Jacob, David, and others (Dialogus cum Tryphone Jedaeo 86; Migne 1857a:679-682), telling him about the new covenant and that Jesus was both the Messiah of the Old Testament and the Logos through whom God has revealed himself to them (cf. Schaff 1885a:421).

Tertullian (160-220/240) was the first great Theologian of North Africa, and the first one to introduce the term trinitas [Trinity] to the vocabulary of the Christendom. He also introduced the teaching that one God revealed himself in 'tres personae' [three Persons] (Burton 2007:132). In his Apologeticum, he defended Christians who opposed the pagan laws of Rome, stating that Christianity has filled every place in the world, and has only left the temples of the gods to Rome (Apologeticum 37). He was the one who said to the rulers of the Roman Empire (cf. Apologeticus 1): Plures efficimur quotiens metimur a vobis; semen est sanguis Christianorum [The oftener we are mown down by you, the more in number we grow; the blood of Christians is (the) seed (of the Church) Apologeticus 50 (Oehler 1999)].

\section{The Three Forms (Formularies) of Unity}

The Three Formularies of the Reformed Churches (cf. RCUS 2011) originated in the 16th and 17th centuries. Concerning the Trinity, the Heidelberg Catechism question and answer 25, as well as the Confessio Belgica [Belgic Confession of Faith] Article 8, are in agreement with the catechism picture given at the beginning of the article, while the Canons of Dordt or Dort do not directly refer to it. In the Catechism (RCUS 2011) we read:

Question 25: Since there is only one God why do you speak of three Persons, Father, Son, and Holy Spirit?

Answer: Because God has so revealed himself in his Word that these three distinct Persons are the one, true, eternal God. (p. 23)

The texts given by the Catechism in support of the fact that there is only one God are rightly Deuteronomy 6:4, complemented by Isaiah 44:6, 45:5, and 1 Corinthians 8:4 and 6 . The texts given for the fact that God has revealed himself in his Word as Father, Son, and Holy Spirit ('three Persons') are mostly texts referring to the Spirit of Yahweh in the Old Testament, and the Holy Spirit in the New Testament (Gn 1:2-3 [much debatable]; Is 61:1; 63:1-10; Lk 4:18; Jn 14:26; 15:26), while Matthew 3:16-17 refers to the baptism of Jesus; Matthew 28:18-19 resembles Jesus' command to his disciples to baptise in the Name of the Father, the Son, and the Holy Spirit; 2 Corinthians 13:14 is a blessing in the Name of Jesus Christ, God, and the Holy Spirit; Galatians 4:6 relates how God sent the Spirit of his Son to us; and Titus 3:5-6 states that the Holy Spirit is poured out through Jesus Christ. 
Apart from these texts (on one God), the rest of the texts are not really in support of one God.

The header of the Confessio Belgica Article 8 (RCUS 2011:5556) states: 'God is One in Essence, yet distinguished in three Persons', and elaborates as follows:

According to this truth and this Word of God, we believe in one only God, who is one single essence, in which are three Persons, really, truly, and eternally distinct, according to their incommunicable properties; namely, the Father, and the Son, and the Holy Ghost ... these Persons thus distinguished are not divided nor intermixed; for the Father had not assumed the flesh, nor had the Holy Spirit, but the Son only. The Father had never been without his Son, or without his Holy Spirit. For they are all three co-eternal and co-essential. There is neither first nor last; for they are all three one, in truth, in power, in goodness, and in mercy.

This Confession unconvincingly uses the Comma Johanneum (1 Jn 5:7) ${ }^{28}$ and Hebrews 1:3 (reference to God and the Son) as proof for the three Persons.

From both these Formularies it is clear that the texts quoted are not depicting a Triune God (except for the Comma Johanneum), as it is not the intention of the Bible to try and prove that God is in fact a Trinity. The notion of the Trinity actually has its roots in the Early Church Era, as stated above.

\section{The Trinity}

Up to this point, the discussion took a historical route to show the development or developments in the concept of the Trinity. From here onwards, the authors are working to the thesis mentioned in the introduction.

\section{Biblical references to God}

\section{The Old Testament picture}

In the Old Testament times, the people of God knew him by his Name, Yahweh, as one God (Dt 6:4). ${ }^{29}$ In Exodus 3:14-15 Yahweh answers Moses' question (Ex 3:13) as to what his Name is, stating:

I am who I am. Go and tell the Israelites that 'I am' has sent you to them. Tell them that Yahweh, the God of their ancestors Abraham, Isaac, and Jacob - has sent you to them. This is my eternal Name, the Name that everyone shall call me.

In this passage the two terms I am (who I am) and Yahweh are used synonymously.

Although there are references to the 'Angel of God' (not 'angels [of $\left.\mathrm{God}^{30}\right]^{\prime}$ ) in the Old Testament, the authors

28. Because the Comma Johanneum only appears in four minor Greek manuscripts and was never quoted by any of the Greek Church Fathers, it is omitted from the most recent text and therefore not part of the Greek New Testament anymore (Metzger 1971:715-716).

29.Space does not allow us to refer to and discuss all the titles of Yahweh, like Elohim (Gn 1), El Shaddai (Gn 17:1-2) and the like.

30.The phrase 'angels (of God)' is used frequently in the Old Testament and is not once a reference to Yahweh himself (cf. Gn 19:1-15; 32:1; Ps 8:5). regard the Angel of God as God himself and therefore not as another Person of the Godhead. ${ }^{31}$ Texts referring to the 'Angel of God' (cf. Gn 21:17; 31:11; Ex 14:19; Nu 22:22; Ju 13:6) are more than oft referring to Yahweh himself. In the very first appearance of the 'angel of God' in the Old Testament in Genesis 21:17, 19, we read: God heard the boy crying, and the angel of God called to Hagar from heaven and said to her, 'What is the matter, Hagar? Do not be afraid ...' Then God opened her eyes and she saw a well of water. 'God' and 'angel of God' are so closely linked here that it is in fact God himself talking to Hagar all the time. In Genesis 31:11, 13 Jacob addressed his two wives: 'The angel of God said to me in the dream, "Jacob"... I am the God of Bethel ..."'. Here the 'angel of God' clearly said 'I am the God ...'.

There are also references to the 'Spirit of God' (cf. Ex 31:3; 35:31; Nm 24:2; 1 Sa 10:10), which was not seen as a separate being, but mostly as a part of God himself. With reference to the 'Spirit of God', 32 Exodus 31:1-3 (cf. Ex 35:31) is a good example where Yahweh refers to his 'Spirit' as his gift (as a part of him) to Bezalel: Then Yahweh said to Moses, 'See, I have chosen Bezalel ... and I have filled him with the Spirit of God ...'. Passages where 'God' and the 'Spirit of God' are so intertwined that it can be regarded as one are Job 33:4 (The Spirit of God has made me; the breath of the Almighty gives me life) and Psalm 106:33 (... for they [the Israelites] rebelled against the Spirit of God ...).

The deduction made from the Old Testament is that God is seen as ONE, and not as a plurality of beings, despite references like 'Angel of God' and 'Spirit of God'.

\section{The New Testament picture}

As Jesus was incarnated, and after his Ascension, the concept his followers had about Yahweh was broadened by the concept of the Father and the Son and, after the outpouring of the Holy Spirit in Acts 2, the Holy Spirit (almost) as separate, but still intertwined Persons. Amidst the vast array of references in the New Testament, where one can interpret that God (the Father), Jesus (the Son) and the Holy Spirit are three 'separate' Persons (each with an own function), we also find certain texts that emphasise the ONEness of God: Or is God the God of Jews only? Is he not the God of Gentiles too? Yes, of Gentiles too, since there is only one God ( $\operatorname{Rm~3:29-30);~...~one~Lord,~one~faith,~one~}$ baptism; one God and Father of all, who is over all and through all and in all (Eph 4:5-6); For there is one God and one mediator between God and mankind, the man Christ Jesus (1 Tim 2:5); You believe that there is one God. Good! Even the demons believe that - and shudder (Jas 2:19).

31.Some people argue that the Angel of God was in fact 'Yeshua' - Jesus (Juncker 1994:221-250; Jews for Jesus 2018).

32.The Old Testament already indicates that when the Spirit of God comes upon people they start to prophesy, like in 1 Samuel $(10: 10 ; 19: 20-23)$, or to simply say what God wants them to say, like in 2 Chronicles 15:1 and 24:20. In 1 Chronicles what God wants them to say, like in 2 Chronicles $15: 1$ and 24:20. In 1 Chronicles
$12: 18$ (also 1 Chr 28:12) there is a reference to the Spirit alone, coming on Amasia, and in Ezekiel 11:1 (also vs 24), where the Spirit had lifted the prophet up. 
In certain texts, Jesus and the Father are specifically depicted as One. John 1:1 is a good example: In the beginning was the Word [Jesus], and the Word was with God, and the Word was God. John 1:18 confirms this statement: No one has ever seen God, but the one and only Son, who is himself God and is in closest relationship with the Father, has made him known. In John 10:30 Jesus states: I and the Father are one, complemented by John 12:45: The one who looks at me is seeing the one who sent me (cf. Jn 14:9). Hebrews 1:3 (as part He 1) supplies a solid description of Jesus-as-part-of-God: The Son is the radiance of God's glory and the exact representation of his being, sustaining all things by his powerful word. ${ }^{33}$

If, then, God was always ONE, then why is he, especially in the New Testament, depicted as three? Within the New Testament context, it made sense for Jesus to present himself as the Son of Yahweh - called the Lord or the Father (with reference to the Old Testament use of 'Father'; see below), serving as a perfect metaphor for a well-known and precious notion to the Jews - the household.

\section{Family metaphor: The household of God}

During the era of the Old and New Testament, the family was very precious to ancient Israel: Their society was structured along kinship lines (Wright 1983:37), while the household was regarded as a source of Divine blessing (Colijn 2004:74). For the ancient Hebrew family, 'household' included the father, mother and children, as well as the sons' wives and children, the husband's parents, unmarried sisters, and his brothers (and their families), apart from the servants and slaves, easily consisting of 50 to 100 people $^{34}$ (cf. Colijn 2004:73).

Already in the Old Testament Yahweh revealed himself as and was called Father (of Israel) (Jer 31:9; Is 64:8), while Israel was his firstborn son (Ex 4:22) to whom he gave birth (Dt 32:18), and he lived in his Temple - the house of Yahweh (Is 66:1). In certain passages, house of Yahweh can refer to both Israel and the Temple (Nm 12:7; Jer 12:7; Hos 8:1). It was from this household that these people derived their identity (Malina 1993:63-73; Meyers 1997:21). According to Dearman (1998:117), 'The Old Testament presents the family as a metaphor for God's relationship with Israel and a vehicle of grace for human beings'.

The family was still the centre of religious life in the New Testament (Colijn 2004:76) and a continuation of the Old

\footnotetext{
33.This reminds us strongly of the words of Tatian (He was a 'scholar of Justin Martyr' -

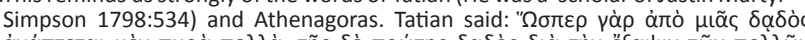

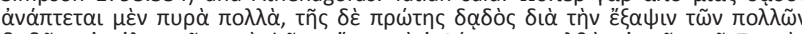

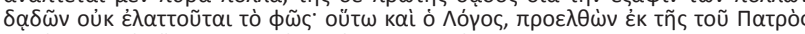

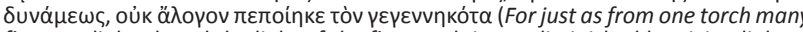
fires are lighted, and the light of the first torch is not diminished by giving light to the many torches, so the Logos, coming forth from the power of the Father, has not divested of the Logos-power him who begat him; Oratio adversus Græcos 5. Migne 1857a:817). According to Athrenagoras, $\Omega \varsigma$ yà $\rho$ Oróv $\phi \alpha \mu \varepsilon v$, kai Yiòv tòv $\wedge$ óyov

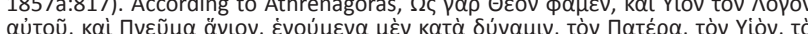

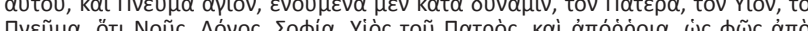

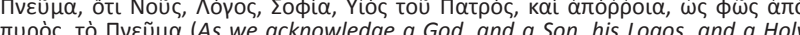

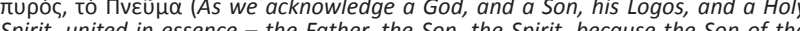
Spirit, united in essence - the Father, the Son, the Spirit, because the Son of the Father is the Intelligence, Reason, Wisdom, and the Spirit an effluence, as light from fire; Legatio pro Christianis 24; Migne 1857c:945).
}

34.Jacob's household serves as a good example, consisting of 70 members ( $G n$ 46:27).
Testament metaphor. Introducing the New Testament time, Jesus ${ }^{35}$ was born as a baby, having a mother (being impregnated by God himself, referred to as the Holy Spirit in Lk 1:36) and a father, grew up in a family, and, being the eldest son, supported his father in his business.

Yahweh's revelation to his followers was depicted with household terms, like Father and (Jesus as his) Son (cf. Jn 1:14; 3:16,18; Rm 15:6; 1 Jn 2:23; 4:9), and Father of his followers as his sons or children (cf. 1 Jn 3:1; Mt 23:9); the Temple is referred to as the house of God (Mt 12:4), while the followers of Jesus are referred to as brothers or sisters of each other (Mt 23:8) and brothers and sisters of Jesus (He 2: 11; Mt 12:50). Jesus also illustrated his close relation with God in household terms: All things have been committed to me by my Father. No one knows the Son except the Father, and no one knows the Father except the Son and those to whom the Son chooses to reveal him (Mt 11:27; cf. Jn 1:18). He even called Yahweh Abba, Father in Mark 14:36, which was an Aramaic term depicting an intimate family relationship. ${ }^{36}$

When he became a Rabbi, Jesus (mostly indirectly) referred to

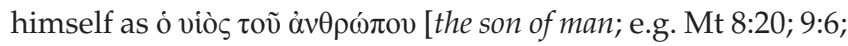

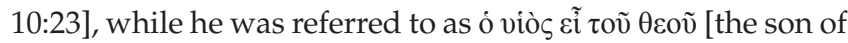
God] by his disciples (Mt 14:33), Peter (Mt 16:16), a centurion who realised by himself that Jesus is the Son of God (Mt 27:54), and even by evil spirits (Mt 8:29).

Even during the Early Church Era, the household was central to the activities of the Christians and still acted as the basic model for the early Christian communities (cf. Meeks 1983:84), as many Christians gathered in house Churches (cf. Rm 16:5; 1 Cor 16:19; Phm 2).

The household, well-known to the Jews from as early as the Old Testament times, therefore served as the perfect metaphor for depicting the relationship in the New Testament era and afterwards in acceptable terms, between God the Father and God the Son, however, not declaring with this that they were two separate Persons.

\section{The 'hidden link'}

The fact that God presented himself in Jesus as the Son of God, to fit in with the household metaphor of the time, could have led to the contemplation of the Early Church (and something that is still prevalent) that the monotheistic religion (only Yahweh) of the Jews was extended to three 'separate' Persons, Father, Son and Holy Spirit. When an explanation is requested, the words of Origen (referred to in the introduction) could merely have been used - 'it is a mystery'. The researchers could not find any document of the Church Fathers where the transition from a monotheistic religion to a religion consisting of a unity of three Persons is explained- except, maybe, for Tertullian. In his Adversus Praxean 31 he argued: Ceterum

35. His Name can be translated with Yahweh saves; and according to Mt $1: 22$, the people will refer to him as Immanuel, which can be translated with God with us.

36.According to Paul, even the Holy Spirit calls Yahweh 'Abba, Father' (Ga 4:6), while the same Spirit determines Yahweh's children to cry out, 'Abba, Father' (Rm 8:15). 
Iudaicae fidei ista res, sic unum deum credere ut filium adnumerare ei nolis et post filium spiritum. quid enim erit inter nos et illos nisi differentia ista? quod opus evangelii...si non exinde pater et filius et spiritus, tres crediti, unum deum sistunt? sic deus voluit novare sacrament umut nove unus crederetur per filium et spiritum, ut coram iam deus in suis propriis. [But, (this doctrine of yours bears a likeness) to the Jewish faith, of which this is the substance - so to believe in one God as to refuse to reckon the Son besides him, and after the Son the Spirit. Now, what difference would there be between us and them? What need would there be of the gospel ... if thenceforward the Father, the Son, and the Spirit are not both believed in as three, and as making one only God? God was pleased to renew his covenant with man in such a way as that his unity might be believed in, after a new manner, through the Son and the Spirit, in order that God might now be known openly, in his proper Names and Persons, who in ancient times was not plainly understood, though declared through the Son and the Spirit; nominibus et personis cognosceretur qui et retro per filium et spiritum praedicatus non intellegebatur (Evans 1948:129; cf. Schaff 1885c:1405)]. This will be discussed more in the conclusion.

\section{God's omnipresence}

Omnipresence is an attribute belonging to God alone, traditionally described as his quality of being present in all places (everywhere) at all times (at any time), with the implication that he is not bound by time or space. This relates to all alternate galaxies and dimensions - not just ours.

Thomas Aquinas (1947) explained the omnipresence of God in his Summa Theologica (part 1, question 7) as follows: Considerandum est de eius infinitate...attribuitur enim Deo quod sit ubique et in omnibus rebus, inquantum est incircumscriptibilis et infinitus [We must consider the Divine infinity... for God is everywhere, and in all things, inasmuch as he is boundless and infinite; Harvey 2015:368]. Irenaeus ${ }^{37}$ in his Adversus Haereses (2.30.9) looks at it from another angle: Et omnia aptavit et disposiut sapientia sua, et omnia capiens, solus autem a nemine capi potest: ipse fabricator, ipse conditor, ipse inventor, ipse factor, ipse Dominus omnium: et neques praetor ipsum, neque super ipsum [And he has fitted and arranged all things by his wisdom, while he contains all things, but he himself can be contained by no one: he is the former, he is the builder, he is the discoverer, he is the creator, he is the Lord of all; and there is no one besides him or above him; Lashier 2009:194]. With this statement he came close to the viewpoint of the authors of this article.

Athanasius has the view that both God's omnipresence and transcendence are depicted in his incarnation through Christ. While God revealed himself to us through Christ, he did not lose anything of his Divinity. In his Oratio de Incarnatione Verbi 17, he explained:

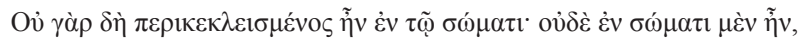

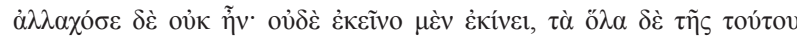

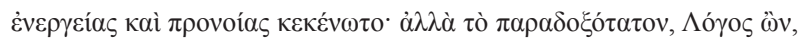

37.Polycarp, who was a disciple of the apostle John, was his teacher (Simpson 1798:540).

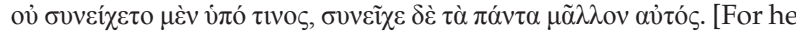
was not, as might be imagined, circumscribed in the body, nor, while present in the body, was he absent elsewhere; nor, while he moved the body, was the universe left void of his working and providence; but, thing most marvellous, Word as he was, so far from being contained by anything, he rather contained all things himself; Migne 1857g:125].

It is interesting to note that the seven Ecumenical Councils did not directly touch on the topic of God's omnipresence. There is also no reference to God's omnipresence in the Three forms of Unity.

Although the term omnipresence (just like Trinity) does not occur in the Bible, there are more than enough verses depicting it: ${ }^{38}$

- His presence fills heaven and earth (Ps 139:7-10; 113:4-6; Is 66:1; Jer 23:24; Ac 17:24).

- He dwells everywhere and knows my every movement (Ps 139:3, 5; Is 57:15).

- He is always near us; he is there where people pray (Is 43:2; Mt 18:20; Ac 17:27).

- His eyes are and/or see everywhere; they see what is done in secret (Job 34:21; Ps 32:8; Pr 15:3; Mt 6:6; He 4:13).

- Nothing can contain him; he contains everything (1 Ki 8:27; Col 1:17).

The Bible seemingly takes God's omnipresence for granted and merely celebrates it, as seen above, although it was the belief of the people during the Old Testament times that every territory or country or people group had their own god or gods who 'lived' with and/or among them - the gods were therefore territorialised (cf. De Vaux 1980:325-330; Clements 1978:54). In the New Testament, Jesus told the Samaritan woman that this would no longer be the case: God's followers could now worship him 'in the Spirit and in truth' anywhere they want to worship him (Jn 4:19-24). This made God 'more omnipresent' to his followers, compared to the Old Testament.

The chapter in the Bible that refers most to the omnipresence of God is Psalm 139 (at least the first 18 verses). In this Psalm, the poet celebrates God's closeness to him (vss. 1-6), followed by an in-depth description of God's omnipresence (vss. 7-12): 'Where can I go from your Spirit? Where can I flee from your presence? If I go up to the heavens, you are there; if I make my bed in the depths, you are there. If I rise on the wings of the dawn, if I settle on the far side of the sea, even there your hand will guide me, your right hand will hold me fast. If I say, "Surely the darkness will hide me and the light become night around me", even the darkness will not be dark to you; the night will shine like the day, for darkness is as light to you'.

Verses 13-18 portray God as in fact being the creator of every person, and how his 'eyes' are watching (over) the growing body inside the womb.

38.These are only examples of a vast array of texts in the Bible referring to God's omnipresence. 


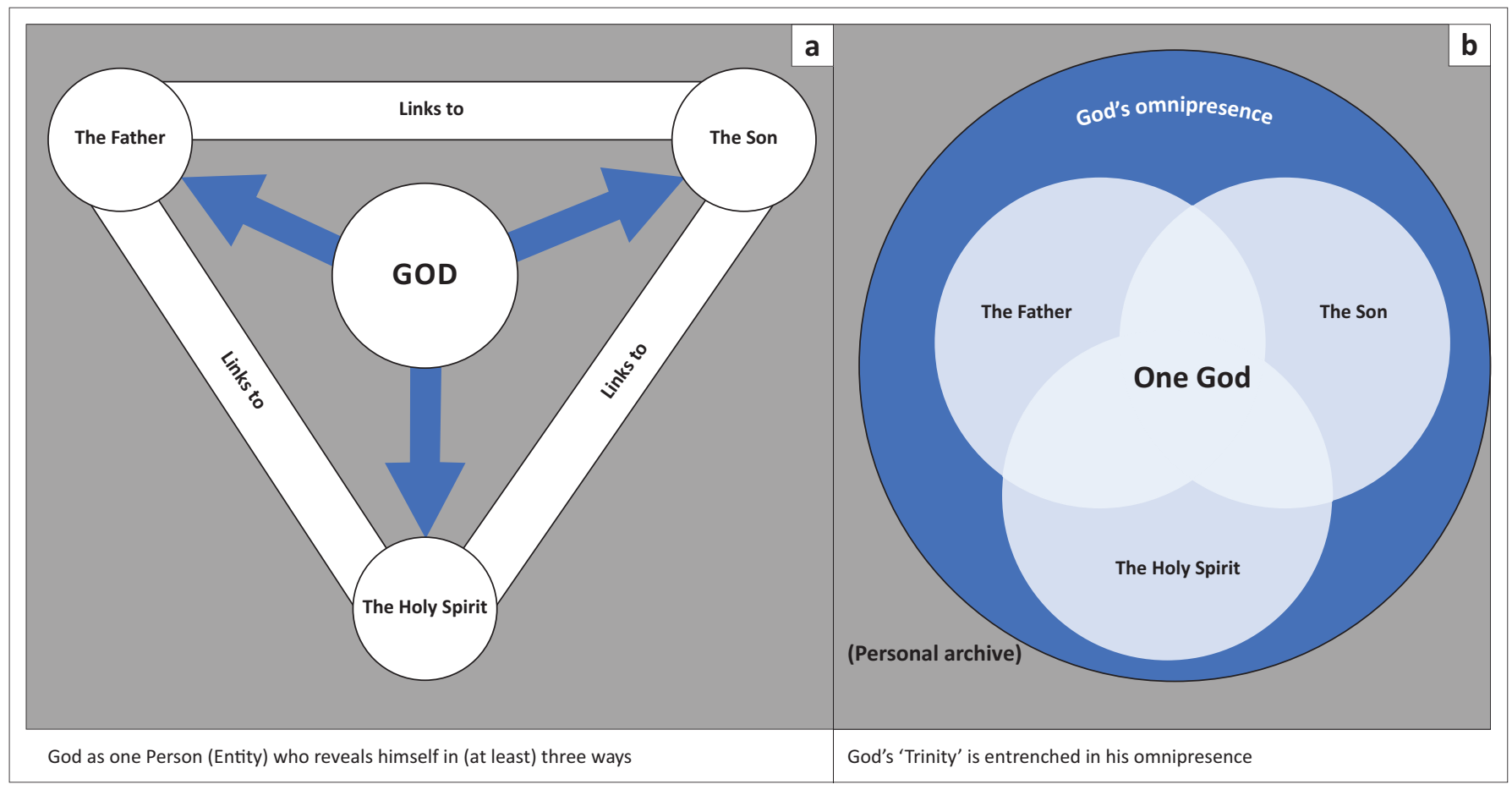

FIGURE 2: An alternative point of view; (a) God as one Person (Entity) who reveals himself in (at least) three ways; (b) God's 'Trinity' is entrenched in his omnipresence.

\section{The 'hidden link'}

According to the sources mentioned above, the fact that God is omnipresent means that he can be everywhere at any time. These sources do not reduce his ability to be everywhere at the same time, but they do not mention once that God can be anybody simultaneously. This will be discussed in the next section.

\section{Conclusion: An alternative understanding of 'God as One'}

The authors are convinced that the view of all the Unitarians or Modalists or Sabellianists points in the right direction, but that they distort their point of view with their own dogma, therefore expressing themselves in contrast to the ruling view. Trying to make Jesus a secondary God or referring to masks of God is in fact a denial of the Holy Trinity, making him three separate Persons. In too many places in the New Testament, we do see that Jesus and even the Holy Spirit are equal to, or one with, God. The question that the reader could ask is: How does one link a unitarian view with the conviction that the Trinity does exist? The answer may be found in God's omnipresence, because it is the conviction of the authors that God's 'Trinity' is entrenched in his omnipresence.

God's omnipresence refers to him being everywhere at any time, also including that he can be anyone of the three Persons at any time - simultaneously. To simplify it: God can be in two different places at the same time. What makes his omnipresence complete is that he can be two different Persons in these two places at the same time, and for that matter he can be as many Persons as he chooses to be, in as many places as he chooses to be, at the very same moment. He does not need to be separate Persons to fulfil this task.

If God is able to be different Persons in different places at the same time, it implies that he can be God the Father to an individual who prays to the Father; God the Son to another person needing a friend; God the Holy Spirit at a worship event and God the Holy Spirit to one needing his comfort all at the very same time and moment. He can hang on the cross as God the Son and cry out to God the Father, 'Eloi, Eloi, lema sabachthani?' [My God, my God, why have you forsaken me? - Mk 15:34]. He can be God the Father who lives in heaven, while God the Son dies on the cross. This is the mindboggling reality of the God we worship. Instead, therefore, to say that he is three distinct Persons, we postulate that he reveals himself to us as three Persons. These are not three masks of God, but three ways in which he shows his Oneness and compassion with humankind, three ways in which he constantly appears to his children (cf. Figure 2).

This is no effort to start a new theology. To imply that 'the Church was wrong all the time' would be a 21st-century heresy. However, this is an effort to bring the reader to a point where he or she will start to rethink the notion of the concept 'Trinity' within a modern context, and hopefully involve other scholars to also discuss the Trinity in the way they understand it. This will also contribute to the worship of God as One and not 'separating' him as the Churches do today.

\section{Acknowledgements Competing interests}

The authors declare that they have no competing interests with regard to the writing of this article. 


\section{Authors' contributions}

W.H.O. and E.O. worked and did the research together. W.H.O. did the writing of the research and E.O. corrected it. Both authors read and approved the final version of the manuscript.

\section{References}

Armstrong, G.T., 1962, Die Genesis in der alten Kirche: die drei Kirchenväter, Mohr, Tübingen.

Britannica Concise Encyclopedia, 2006, Arianism, rev. and Expanded edn., Encyclopedia Britannica, Inc., Chicago, London.

Burton, K.A., 2007, The Blessing of Africa, InterVarsity Press, Downers Grove, IL.

Clements, R.E., 1978, Old Testament Theology: A Fresh Approach, Marshall, Morgan $\&$ Scott, London.

Coleti, N., 1727, Conciliorum, Tomus Quartus, viewed 03 October 2017, from https:// books. google.co.za/books?id=glpEAAAAcAAJ\& printsec=frontcover\&source= books.google.co.za/books? id=glpEAAAAcAAJ \&p
bs_ge_summary_r $\&$ cad $=0 \# \mathrm{v}=$ onepage $\& \& \mathrm{f}=$ true

Colijn, B.B., 2004, 'Family in the Bible: A brief survey', Ashland Theological Journal $36,73-84$.

Dearman, J.A., 1998, 'The family in the Old Testament', Interpretation: A Journal of Bible and Theology 52(2), 117-129.

Deist, F., 1984, A concise dictionary of Theological terms, JL van Schaik, Pretoria.

De Vaux, R., 1980, Ancient Israel: Its Life and Institutions, transl. J. McHugh, Darton, Longman \& Todd, London.

Early Church Texts, s.a., The Nicene Creed-agreed at the Council of Constantinople in 381, viewed 21 September 2017, from http://www.earlychurchtexts.com/public/ nicene_creed.htm

Evans, E., 1948, Adversus Praxean, SPCK, viewed 13 September 2017, from http:// www.tertullian.org/latin/adversus praxean.htm

Evans, G.A. \& Tov, E. (eds.), 2008, Exploring the Origins of the Bible: Canon formation in historical, literary, and theological perspective, Baker Academic, Grand Rapids, MI.

Fogarty, M.E., 2004, 'Egyptian Christianity: An historical examination of the belief systems prevalent in Alexandria C.100 B.C.E. - 400 C.E. and their role in the shaping of Early Christianity', Unpublished MPhil Dissertation, University of Stellenbosch.

Garlington, D. (ed.), 2008, Studies in the new perspective on Paul: Essays and reviews, Wipf and Stock Publishers, Eugene.

Harvey, W.W., (ed.), 2015, Adversus Haereses: Textu Graeco in Locis Nonnullis Locupletato, Versione Latina Cum Codicibus Claromontano AC Arundeliano Denuo Coll., Praemissa de Placitis Gnosticorum Prolusione, Fragm. Necnon Graece, Syriace, Armeniace, Commentatione Perpetua Et. Endesite Press, Berlin viewed 25 June 2018, from http://www.textexcavation.com/documents/images/ ah2p063.jpg

Hyldahl, J., 2014, 'Clement of Alexandria: Paganism and its positive significance for Christianity', in D. Brakke, A.-C. Jacobsen \& J. Ulrich (eds.), Early Christianity in the context of antiquity. Vol. 15: In defence of Christianity: Early Christian apologists, pp. 139-157, Peter Lang GmbH Europäischer Verlag der Wissenschaften, Frankfurt am Main.

Isichei, E.A., 1995, A history of Christianity in Africa, William B. Eerdmans Publishing Company, Grand Rapids, MI.

Jehovah's Witnesses, 2018, What Do Jehovah's Witnesses believe?, viewed 25 June 2018, from https://www.jw.org/en/jehovahs-witnesses/faq/jehovah-witnessbeliefs/.

Jews for Jesus, 2018, Similarities between the Angel of the Lord and Yeshua, viewed 20 June 2018, from https://jewsforjesus.org/issues-v14-n06/issues-v14-n06/issuesv14-n06/similarities-between-the-angel-of-the-lord-and-y-shua/.

Joüon, P., 2005, A grammar of Biblical Hebrew, transl T. Muraoka, Pontifical Biblical Institute, Rome.

Juncker, G., 1994, 'Christ as Angel: The reclamation of a primitive title', Trinity Journal 15(2), 221-250.

Kelly, J.N.D., 1978, Early Christian doctrines, HarperCollins, New York.

Khazarzar, R., 2006a, Epistula Festalis 39, viewed 02 October 2017, from http:// khazarzar.skeptik.net/pgm/PG Migne/Athanasius $\% 20$ the $\% 20$ Great $\% 20$ of $\% 20$ Alexandria_\%20PG\%2025-28/Epistula\%20festalis\%20xxxix.pdf

Khazarzar, R., 2006b, Orationes contra Arianos, viewed 20 September 2017 from http://khazarzar.skeptik.net/pgm/PG_Migne/Athanasius $\% 20$ the $\% 20$ Great\%20o

Lashier, J.J., 2009, 'The Trinitarian Theology of Irenaeus of Lyons', Unpublished PhD Thesis, Marquette University.

Malina, B.J., 1993, The New Testament World: Insights from Cultural Anthropology rev. edn., Westminster/John Knox Press, Louisville, KY.

Marcovich, M., 1986, Hippolytus Refutatio Omnium Haeresium, Walter De Gruyter Berlin.

McGrath, A.E., 2013, Christian history: An introduction, Wiley-Blackwell, Chichester.
Meeks, W.A., 1983, The first urban Christians: The social world of the Apostle Paul, Yale University Press, New Haven, CT.

Metzger, B.M., 1971, A textual commentary on the Greek New Testament, United Bible Societies, London.

Meyers, C., 1997, 'The Family in Early Israel', in L.G. Perdue, J. Blenkinsopp, J.J. Collins \& C. Meyers (eds.), Families in Ancient Israel, pp. 1-47, Westminster/John Knox Press, Louisville, KY.

Migne, J.-P. (ed.), 1857a, Patrologiae Cursus Completus: Patrologiae Graecae Tomus Unicus (Tatian), Digitized by Google, viewed 21 June 2018, from https://books. google.co.za/books?id=IQURAAAAYAAJ

Migne, J.-P. (ed.), 1857b, Patrologiae Cursus Completus: Patrologiae Graecae Tomus V (Ignatius), Digitized by Google, viewed 21 June 2018, from https://books.google. co.za/books?id=AQRAAAAYAJ

Migne, J.-P. (ed.), 1857c, Patrologiae Cursus Completus: Patrologiae Graecae, Tomus VI (Justin Martyr; Athenagoras), Digitized by Google, viewed 31 August 2017, from https://books.google.co.za/books?id=NKuMu9WNStAC.

Migne, J.-P. (ed.), 1857d, Patrologiae Cursus Completus: Patrologiae Graecae Tomus X (Hippolytus; Dionysius), Digitized by Google, viewed 31 August 2017, from https://books.google.co.za/books?id=74S3-ku1oc4C

Migne, J.-P. (ed.), 1857e, Patrologiae Cursus Completus: Patrologiae Graecae Tomus XI (Origen), Digitized by Google, viewed 04 September 2017, from https://books. google.co.za/books?id=qAkRAAAAYAA

Migne, J.-P. (ed.), 1857f, Patrologiae Cursus Completus: Patrologiae Graecae Tomus XX (Eusebius), Digitized by Google, viewed 04 September 2017, from https://books. google.co.za/books?id=JwYRAAAAYAA

Migne, J.-P., (ed.), 1857g, Patrologiae Cursus Completus: Patrologiae Graecae Tomus XXV (Athanasius), Digitized by Google, viewed 29 October 2017, from https:// books.google.co.za/books?id=AQRAAAAYAAJ

Oden, T.C., 2011, The African memory of Mark: Reassessing early church tradition, InterVarsityPress, Downers Grove, IL

Oehler, F. (ed.), 1999, Tertulliani Liber Apologeticus, viewed 22 October 2017, from http://www.tertullian.org/latin/apologeticus.htm.

Oliver, W.H. \& Van Aarde, A.G., 1991, 'The community of faith as dwelling place of the father', Neotestamentica 25(2), 379-400.

Pedersen, N.A., 2014, 'Aristides', in D. Brakke, A-C. Jacobsen \& J. Ulrich (eds.), Early Christianity in the Context of Antiquity. Vol. 15: In Defence of Christianity: Early Christian Apologists, pp. 35-49, Peter Lang GmbH Europäischer Verlag der Wissenschaften, Frankfurt am Main.

Routh, M.J., 1846, Reliquiae Sacrae: Sive, Auctorum fere jam Perditorum. Secund tertique saeculi post Christum natum quae Supersunt. Accedunt Synodi, et Epistolae Canonicae, Nicaeno Concilio Antiquiores. Editio Altera. Vol III, E Typographeo Academico, Oxonii, viewed 25 June 2018, from https://books google.co.za/books?id=mqNQAAAAcAAJ\&pg=PA377\&lpg=PA377\&dq=DE+D ECRETIS+NIC\%C3\%86N\%C3\%86+SYNODI+CAP. +XXVI\&source=bl\&ots=E6 BhTOVOw\&sig=fCTOb4j72HS4D91RA16-IckCpcg\&hl=en\&sa=X\&ved=0ahU KEwiVOIzUp6TWAhVBLMAKHedXAQMQ6AEIMDAC\#v=onepage\&q=DE\%20 DECRETIS $\% 20$ NIC\%C3\%86N\%C3\%86\%20SYNODI\%20CAP.\%20XXVI\&f=false

Schaff, P. (ed.), 1885a, Ante-Nicene Fathers, vol. 1: The Apostolic Fathers with Justin Martyr and Irenaeus, Christian Classics Ethereal Library, Grand Rapids, MI.

Schaff, P. (ed.), 1885b, Ante-Nicene Fathers, vol. 2: Fathers of the Second Century: Hermas, Tatian, Athenagoras, Theophilus, and Clement of Alexandria (Entire) Christian Classics Ethereal Library, Grand Rapids, MI.

Schaff, P. (ed.), 1885c, Ante-Nicene Fathers, vol. 3: Latin Christianity: Its Founder, Tertullian, Christian Classics Ethereal Library, Grand Rapids, MI.

Schaff, P. (ed.), 1885d, Ante-Nicene Fathers, vol. 4: The Fathers of the Third Century: Tertullian Part IV; Minucius Felix; Commodian; Origen, Christian Classics Ethereal Library, Grand Rapids, MI.

Schaff, P. (ed.), 1885e, Ante-Nicene Fathers, vol. 9: Recently Discovered Additions to Early Christian Literature; Commentaries of Origen, Christian Classics Ethereal Library, Grand Rapids, MI.

Schaff, P. (ed.), 1885f, Nicene and Post-Nicene Fathers. Series 2, vol. 1: Eusebius Pamphilius: Church History, Life of Constantine, Oration in Praise of Constantine, Christian Classics Ethereal Library, Grand Rapids, MI.

Schaff, P. (ed.), 1885g, Nicene and Post-Nicene Fathers. Series 2, vol. 4: Athanasius: Select Works and Letters, Christian Classics Ethereal Library, Grand Rapids, MI.

Schaff, P. (ed.), 1885h, Nicene and Post-Nicene Fathers. Series 2, vol. 8: Basil: Letters and Select Works, Christian Classics Ethereal Library, Grand Rapids, MI.

Schaff, P. (ed.), 1885j, Nicene and Post-Nicene Fathers. Series 2, vol. 14: The Seven Ecumenical Councils, Christian Classics Ethereal Library, Grand Rapids, MI.

Schaff, P. (ed.), 1894, A religious encyclopaedia or dictionary of biblical, historical, doctrinal, and practical theology, 3rd edn., vol. 1, Funk \& Wagnalls Company, Toronto.

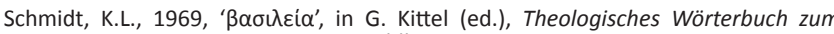
Neuen Testament, pp. 580-590, Kohlhammer, Stuttgart.

Schmidt, W.H., 1964, Die Schöpfungsgeschichte der Priesterschrift, WMANT 17, Neukirchener-Verlag des Erziehungsvereins, Neukirchen-Vluyn.

Simpson, D., 1798, An Apology for the Doctrine of the Trinity: Being a Chronological View of what is recorded concerning, the Person of Christ, the Holy Spirit, and the blessed Trinity, whether in the sacred Writings, or in Jewish, Heathen, and Christian Authors, Trinty, whether in the sacred Writings, or in Jewish, Heathen, and Christian Authors, Dilly, London, viewed $01 \mathrm{June} 2018$, from https://books.google.co.za/books? id= CNNAQAAMAAJpg-PA534\&lpg=PA534\&dq=apologies+on+the+trinity\&source= bl\&ots=j2_C6ul \&mZ\&sig=7IE7btIKMa9AwksQQSMYhKfpRNU\&hl=en\&sa=X\&ved=
OahUKEwisxLLRI-TbAhUKasAKHaAOAtwQ6AEILjAB\#v=onepage\&q=apologies $\% 20$ OahUKEwisxLLRI-TbAhUKasAK
on $\% 20$ the $\% 20$ trinity $\& f=$ false 
Synaxis.info, s.a., A synopsis of the seven ecumenical councils, viewed 31 August 2017 from http://www.synaxis.info/synaxis/8 law/c ecumenical/Ecum01-7/synopsis. htm

The Reformed Church in the United States (RCUS), 2011, The Three Forms of Unity, viewed 13 September 2017, from http://www.rcus.org/wp-content/ uploads/2013/09/Three-Forms-of-Unity-2011-edition.pdf

Torell, J.S., 2018, United Pentecostal Church, European-American Evangelistic Crusades, viewed 20 June 2018, from http://www.eaec.org/cults/ unitedpentecostal.htm

Thomas Aquinas, 1947, The Summa Theologica, trans. Fathers of the English Dominican Province, Benziger Bros. edition, viewed 08 October 2017, from http:// dhspriory.org/thomas/summa/FP.html\#TOCO2

Thornton, J., 2007, The CEcumenical synods of the orthodox church: A concise history Center for Traditionalist Orthodox Studies, Etna.

Triumphpro, s.a., Early church fathers understood the truth! Who or what is God, the Logos, and Man?, viewed 04 October 2017, from http://www.triumphpro.com/ logos-church-fathers.htm
Ulrich, J., 2014, 'Apologists and apologetics in the second century', in D. Brakke, A.-C. Jacobsen \& J. Ulrich (eds.), Early Christianity in the context of antiquity. Vol. 15 In Defence of Christianity: Early Christian Apologists, pp. 1-32, Peter Lang GmbH In Defence of Christianity: Early Christian Apologists, pp. 1-32,
Europäischer Verlag der Wissenschaften, Frankfurt am Main.

United Apostolic Church, 2018, Welcome! to UAC Ministries, viewed 20 June 2018, from https://www.uacministries.org/

Van der Watt, J.G. \& Joubert, S., 2002, Die Boodskap: Ou en Nuwe Testament, Christleike Uitgewersmaatskappy, Vereeniging.

Verhoef, A.H., 2011, 'Trinity, time and ecumenism in Robert Jenson's theology', Nederduitse Gereformeerde Teologiese Tydskrif 52(1 \& 2), 247-256.

Von Harnack, A., 1961, History of Dogma, vol. 1, transl. N. Buchanan, Christian Classiscs Ethereal Library, Grand Rapids, ML.

Westermann, C., 1984, Genesis 1-11, vol 1, transl. J.J. Scullion, SPCK, London.

Williams, D.H., 2011, Modalism. The Encyclopeadia of Christian civilization, 15391540, Blackwell Publishing Ltd, Oxford.

Wright, C.J.H., 1983, An eye for an eye: The Place of Old Testament Ethics Today, InterVarsity Press, Downers Grove, IL. 